\title{
Acetaminophen-Induced Nephrotoxicity and Cystatin-C
}

\author{
Eda Dokumacioglu* and Hatice Iskender \\ Department of Nutrition and Diebetics, Artvin Coruh University, Turkey
}

Submission: February 10, 2017; Published: February 23, 2017

*Corresponding author: Eda Dokumacioglu, Department of Nutrition \& Diabetics, Artvin Coruh University, Turkey, Email: eda_ozcelik@yahoo.com

Abstract

One of the most important health problems that researchers and pharmaceutical industry collaborate globally to tackle is the druginduced kidney diseases, and they are thought to be the result of direct nephrotoxicity and adverse immunological reactions. Paracetamol, also known as acetaminophen is commonly prescribed antipyretic and analgesic drug producing dose-dependent toxicity of liver and renal. This review will focus on the mechanisms of acetaminophen-induced nephrotoxicity and biomarkers that can be used for early assessment of nephrotoxicity.

Keywords: Acetaminophen; Dose-dependent toxicity; Nephrotoxicity; Creatinine fragmentation

\section{Introduction}

\section{Mechanism of acetaminohen-induced nephrotoxicity}

One of the most important health problems that researchers and pharmaceutical industry collaborate globally to tackle is the drug-induced kidney diseases, and they are thought to be the result of direct nephrotoxicity and adverse immunological reactions. Understanding the mechanisms of action of nephrotoxicity a in relation with mortality is important for biological tracing of toxic compounds and developing treatment modalities [1]. The kidney is sensitive and dinamic organ required by the body to perform various major functions including the protection of homeostasis, regulation of the extracellular environment, such as detoxification, and excretion of toxic metabolites and drugs [2,3]. Drug-induced nephrotoxicity has been shown to cause to exert their toxic effects by one or more common pathogenic mechanisms. The dangerous factors that cause sus $\neg$ ceptibility to the damage are present in most people with the occurrence of drug-induced nephrotoxicity $[2,4]$. At therapeutic doses, acetaminophen is metabolized via glucuronidation and sulfation reactions occurring primarily in the liver which result in the water-soluble metabolites that are excreted via the kidney. When large doses of acetaminophen is taken, there is more vigorous depletion of glutathione as well as production of toxic metabolites, which induced renal or kidney damage, leaving large quantities of unbound reactive metabolite. Homeostasis of the body is disrupted by this process and to start apoptosis or programmed cell death, cause to tissue necrosis and finally to organ dysfunction [5]. Acetaminophen overdose consume antioxidant enzymes in renal tissues and to increase lipid peroxidation. Acetaminophen has raisen levels of urea and creatinine leading to uremia. Acetaminophen overdose is related with imbalance of creatinine and urea levels, rising in plasma concentration of these parameters are considered dependable for research to drug-induced nephrotoxicity in human or animals. In nephrotoxicity, increased plasma urea is due to the higher rate of plasma urea production, which exceeds the rate of urea clearance and, therefore tissue creatinine fragmentation increases plasma creatinine levels [6,7]. Several studies have shown that acetaminophen causes oxidative damage, including tissue lipid peroxidation, inhibitions of enzyme and reductions in glutathione levels and changes of enzymatic and non-enzymatic antioxidant systems [8].

\section{Cystatin-C}

Drug-induced renal diseases are one of the serious health problems around the world. Biomarkers are becoming increasingly important to for predicting disease prognosis and disease treatment [9]. Serum cystatin-C is a non-glycosylated protein and, mainly used as a biomarker of kidney function. It has shown promise as a replacement for serum creatinine in estimation of glomerular filtration rate $[9,10]$. Cystatin-C is completely catabolized in the proximal renal tubule and is not returned to blood. Age, gender, protein intake, race, and muscle mass doesn't effect to the levels of serum cystatin-C. When glomerular filtration rate begins to decrease in the body, serum cystatin-C level begins to increase. Production of cystatin-C production is not influenced by renal conditions, 
increased protein catabolism, or nutrition factors. Moreover, it does not change with age or muscle mass like creatinine does. Serum cystatin-C has been suggested to be an ideal endogenous marker of glomerular filtration $[11,12]$. The studies shown that serum cystatin- $C$ is a good marker of renal function and use of serum cystatin- $\mathrm{C}$ based glomerular filtration rate may be more beneficial and better for early diagnosis [13].

\section{Conclusion}

Drug-induced toxicity is an im $\neg$ portant part of the kidney diseases. Kidneys are an important organs with many functions in the body, and some of their biochemical and physiological prop erties make them more undefended to toxic damage. Results of literatures confirmed that high doses of acetaminophen causes nephrotoxicity and serum cystatin- $\mathrm{C}$ is a better marker of renal function.

\section{References}

1. Naughton CA (2008) Drug-Induced Nephrotoxicity. Am Fam Physician 78(6): 743-750.

2. Dokumacioglu E, Iskender H, Aktas MS, Hanedan B, Dokumacioglu A, et al. (2016) The effect of sulforaphane on the levels of serum cystatin-c in acetaminopheninduced nephrotoxicity in rats. Dicle Med J 43(3): 383-389.

3. Kim SY, Moon A (2012) Drug-Induced Nephrotoxicity and Its Biomarkers. Biomol Ther (Seoul) 20(3): 268-272.

4. Shahrbaf FG, Assadi F (2005) Drug-induced renal disorders. J Renal Inj Prev 4(3): 57-60.
5. Gopi KS, Reddy AG, Jyothi K, Kumar BA (2010) Acetaminopheninduced Hepato and Nephrotoxicity and Amelioration by Silymarin and Terminalia chebula in Rats. Toxicol Int 17(2): 64-66.

6. Roy S, Pradhan S, Das K, Mandal A, Mandal S, et al. (2015) Acetaminophen Induced Kidney Failure in Rats: A Dose Response Study. Journal of Biological Sciences 15(4): 187-193.

7. Suh KS (2012) Discovery of novel biomarkers for the development of personalized medicine. Translational Medicine S1: e1-e2.

8. Ozcelik E, Uslu S, Burukoglu D, Musmul A (2014) Chitosan and blueberry treatment induces arginase activity and inhibits nitric oxide production during acetaminophen-induced hepatotoxicity. Pharmacogn Mag 10(Suppl 2): S217-S224.

9. Randers E, Erlandsen EJ, Pedersen OL, Hasling C, Danielsen H (2000) Serum cystatin $C$ as an endogenous parameter of the renal function in patients with normal to moderately impaired kidney function. Clin Nephrol 54(3): 203-209.

10. Randers E, Kristensen JH, Erlandsen EJ, Danielsen H (1998) Serum cystatin $\mathrm{C}$ as a marker of the renal function. Scand J Clin Lab Invest 58: 585-592.

11. Newman DJ, Thakkar H, Edwards RG, Wilkie M, White T, et al. (1995) Serum cystatin $\mathrm{C}$ measured by automated immunoassay: A more sensitive marker of changes in GFR than serum creatinine. Kidney Int 47(1): 312-318.

12. Knight EL, Verhave JC, Spiegelman D, Hillege HL, de Zeeuw D, et al. (2004) Factors influencing serum cystatin $C$ levels other than renal function and the impact on renal function measurement. Kidney Int 65: 1416-1421.

13. Murty MSN, Sharma UK, Pandey VB, Kankare SB (2013) Serum cystatin $\mathrm{C}$ as a marker of renal function in detection of early acute kidney injury. Indian J Nephrol 23(3): 180-183.

\section{Your next submission with Juniper Publishers} will reach you the below assets

- Quality Editorial service

- Swift Peer Review

- Reprints availability

- E-prints Service

- Manuscript Podcast for convenient understanding

- Global attainment for your research

- Manuscript accessibility in different formats

( Pdf, E-pub, Full Text, Audio)

- Unceasing customer service

Track the below URL for one-step submission https://juniperpublishers.com/online-submission.php 